\title{
Ses Temelli Cümle Yönteminin İlk Okuma-Yazma Öğretimi Üzerindeki Başarısının Öğretmen Açısından Değerlendirilmesi ${ }^{1}$
}

\author{
DOI: 10.26466/opus.596841
}

\author{
Muhittin Sağırlı* \\ * Dr. Öğr.Üyesi, İstanbul Üni-Cerrahpaşa, Hasan Âli Yücel Eğitim Fakültesi İstanbul/Türkiye \\ E-Posta: muhittinsagirli@istanbul.edu.tr O ORCID: 0000-0001-9558-3891
}

Öz

Çağın gereklerine ve öğrencinin gelişim düzeyine uygun bu becerilerin geliştirilmesi; bazı eğitim yaklaşım ve modellerinin göz önünde bulundurulmasını gerektirmektedir. Bunlar: Çoklu Zekâ, Yapılandırmacı Yaklaşım, Beyin Temelli Öğrenme, Öğrenci Merkezli Öğrenme, Bireysel Farklılklara Duyarlı Öğretim gibi yaklaşım ve modellerdir. Bu yaklaşım ve modeller çerçevesinde geliştirilen Türkçe Öğretim Programı'nda ilk okuma - yazma öğretiminin yöntem olarak Ses Temelli Cümle Yöntemi ile yürü̈tülmesi ön görüllmüştür. Bu Çalışmanın amacl; ses temelli cümle yönteminin, ilk okuma ve yazma öğretimindeki başarısını, yöntemin uygulama basamakları doğrultusunda belirlemek, genel olarak uygulama ve özel olarak da yöntemin uygulama basamaklarında, yönteme bağhl olumlu ve olumsuz yönleri tespit etmektir. Çalısmanın evreni, ilk okuma ve yazma öğretimini ses temelli cümle yöntemi ile yürüten sinff öğretmenleri, örneklemi ise çalışmaya katılan ve ilk okuma ve yazma öğretimini ses temelli cümle yöntemi ile gerçekleştiren 332 sinıf öğretmenidir. Nicel araştırma yöntemi ile betimsel araştırma modeli kullanılan çalışmada, verilere ulaşmak için araştırmacı tarafından oluşturulan veri toplama aracı kullanılmıştır. Öğretimi ses temelli cümle yöntemi ile gerçekleştiren öğretmenlerden oluşan örnekleme uygulanan veri toplama aracl; öğretmenlerin kişisel özellik ve mesleki bilgilerinin yer aldığı birinci bölüm ve öğretimde uygulanan ses temelli cümle yönteminin aşamaları doğrultusunda süreç ve olumlu-olumsuzluklar ile birlikte değerlendirilen ikinci bölümden oluşmaktadır. Veri toplama aracı ile edinilen veriler, istatistik programları ile analiz edilmiş ve bulgular karşılaştırmalı olarak yorumlanmış ve önerilerde bulunulmuştur.

Anahtar Kelimeler: Illk okuma, yazma, program, yöntem, ses temelli cümle yöntemi, bitişik eğik yazı.

\footnotetext{
${ }^{1}$ Bu çalışma 08-11 Mayıs 2017 tarihlerinde Kıbrıs'ta gerçekleştirilen 16. Uluslararası Sınıf Öğretmenliği Eğitimi Sempozyumunda sunulan sözlü bildirinin revize edilmiş halidir.
} 


\title{
Evaluation of Sound-based Sentence Method of Teaching Reading and Writing from The Teacher's Perspective
}

*

\begin{abstract}
Developing skills in accordance with the requirements of our times and the level of development of the student requires some educational approaches and models to be considered. Some of these approaches and models are Theory of Multiple Intelligence, Constructivist Approach, Brain Based Learning, Student Centered Learning and teaching methods that mind individual differences. In the Turkish Teaching Curriculum developed within the framework of these approaches and models, it is decided that reading and writing instruction method will be the Sound-based Sentence Method. The aim of this study is to determine the success of the sound-based sentence method in teaching reading and writing in accordance with the application steps of the method, and to determine the positive and negative effects of the applications of the method, particularly on the individual steps. The universe of the study is the primary school teachers who teach reading and writing using the sound-based sentence method and the sample of the study is 332 primary school teachers who participated in the study and performed the teaching of reading and writing using the sound-based sentence method. Descriptive research model was used with quantitative research method in the study as well as the data collection tool which was formed to reach the data. The data collection tool applied to the sample which consists of teachers who used the sound-based sentence method to teach reading and writing is composed of two parts. The first part includes the characteristics and occupational knowledge of the teachers while the second part includes the evaluation of the process and the positive and negative aspects in accordance with the stages of the voice based sentence method applied in teaching. Results were obtained by analyzing the data collected with the data collection tool with statistical programs and comparatively interpreting the results of the process.
\end{abstract}

Keywords: Reading, writing, program, method, sound-based sentence method, cursive handwriting. 


\section{Giriş}

Bireyin, sosyal yaşamında ve eğitim-öğretim yaşamındaki başarısında en önemli bilgi, becerilerden bir okuma-yazmadır. Buna ilişkin bilgi ve beceriler, nitelikli şekilde ilkokul birinci sınıfta edinilmeye başlar, geliştirilerek kullanımı ise yaşam boyu sürer.

Okuma-yazma bilgi ve becerisinde önemli olan niteliktir. "Okuma yazma nasıl öğretilirse öğretilsin" demek, doğru değildir. Çocuğa kazandırılacak okuma yazma becerisi, "hızlı, doğru, anlayarak ve kavrayarak" okuma ve okuduğundan zevk alma, bir başka anlatımla "eleştirel" bir okuma ve işlek, düzgün bir yazma, ilk okuma-yazma öğretiminin temel hedefidir (Çelenk, 1999, 2003; Tok, Türkay, Tok ve Mazı, 2008).

$\mathrm{Bu}$ kadar önemli yere sahip okuma-yazma bilgi ve becerisinin nasıl kazanıldığ1 şüphesiz son derece önemlidir. Okuma-yazma sürecinin öğretiminde birçok yöntemin varlığından ve uygulanmasından söz etmek mümkündür.

İlk okuma-yazma öğretiminde yöntem oluşturulup uygulama için belirlenirken, ülkede kullanılan dilin yapısı, dilin yazı sistemi, eğitimöğretimle ilgili araştırmalar, teoriler, uygulamalar, çocuğun gelişim özellikleri, kullanılan materyal vb. gibi hususlar belirleyici olmaktadır (Güneş, 1997). Okuma-yazma öğretimi alan uzmanlarının, daha kısa sürede ve daha nitelikli öğretimi gerçekleştirmek için öğrencinin zihinsel, bedensel, duygusal ve sosyal gelişimine en uygun öğretim yöntemini araştırmaları sonucunda birçok yöntem ortaya çıkmıştır. Geliştirilen bu yöntemlerden bazıları Türkiye'de, eğitim-öğretim programlarında da yer alıp uygulanmıştır. İlk okuma-yazma yöntemlerinin belli başlıları şöyle sıralanabilir (Gray, 1964; Akyol, 2015; Güneş, 2007; Çelenk, 2003; Cemaloğlu ve Yıldırım, 2005; Güleryüz, 2002; Göçer, 2014). Harf (Alfabe, Adlandırma, Tesmiye) Yöntemi, Ses (Fonetik, Savti) Yöntemi, Hece (Tehecci) Yöntemi, Sözcük Yöntemi, Cümlecik Yöntemi, BakSöyle Yöntemi, Cümle (Çözümleme) Yöntemi, Hikaye (Öykü) Yöntemi, Karma Yöntemler.

İlk okuma - yazma öğretim yöntemlerini Çelenk (2002; 2005) ve Güneş (2005) şu şekilde sınıflandırmaktadırlar: 
- Fonetik değerlerini öne alan yöntemler (Alfabe yöntemi, ses yöntemi, hece yöntemi) • Okuduğunu anlamayı esas alan yöntemler (cümle yöntemi, kelime yöntemi, öykü yöntemi)

- Karma yöntemler (fonetik-hece, fonetik- kelime, kelime-hikâye cümle). Bu tür sinıflandırmalar dışında, alanda çok ve farklı sinıflandırmalar da görmek mümkündür.

Cumhuriyet dönemi ülkemiz eğitim-öğretim programlarında ilk okuma-yazma öğretim yöntemleri kronolojik olarak şöyle yer almaktadir:

1924 tarihli İlk Mekteplerin Müfredat Programı'nda, harf ve hece yöntemlerinin öğretimde kullanılmayacağı belirtilmiş, okuma yazma öğretiminde ses yöntemiyle sözcük yönteminden birinin kullanılması öğretmenin takdirine bırakılmıştır (Maarif Vekaleti, 1924; Binbaşıŏlu, 1989; 1999; 2003).

1926 tarihli İlkokul Programı'nda, okuma-yazma öğretiminde hecelemeyle sonuçlanan harf (tesmiye) yöntemi ile ses (savti) yönteminin kullanılmayacağı belirtilip, sözcük yöntemiyle karma (muhtelif) yöntemlerinden birini seçme konusunda öğretmen serbest bırakılmıştır (Maarif Vekaleti, 1926).

1936 tarihli İlkokul Programı'nda; ilk okuma - yazma öğretimi alanındaki uygulamaların yeni bir aşamasını oluşturmaktadır. Programda; çocuk ve okuma psikolojisinin doğal gereklerine uyularak, ilk okuma - yazma öğretimine basit cümle ve sözcüklerden başlanıp çözümlemeli ve bireşimsel bir yol izlenerek okuma ve yazma mekanizması kavratılacaktır" ifadesi yer almaktadır. (Illkokul programı, 1936; Binbaşığlu, 2004).

1926 programindan farklı olarak 1936 programinda, basit cümle ve sözcükler ile okuma-yazma öğretimine başlanacağı belirtilmiştir. Bununla artık sentez grubu yöntemlerden çok farklı analiz grubu içinde yer alan sözcük ve cümle yöntemlerine geçildiğini, açıç̧a ve adı belirtilerek verilmese de cümle yönteminin 1936 programina ilk kez girmiş olduğunu görmekteyiz.

1948 tarihli İlkokul Programı'nda; “İlk okuma ve yazmaya basit cümleler ve sözcükler ile başlanacaktır. Zamanla bu cümleler sözcüklere, sözcükler hecelere, heceler ise harflere bölünecek, bu çözümlemeler so- 
nucunda elde edilecek sözcük, hece ve harf ile yeni cümleler ve sözcükler oluşturulacaktır..." denilmektedir (İlk Okul Programı, 1948).

1968 tarihli İlköğretim Programı́nda; “ilk okuma ve yazma öğretimine öğrencilerin anlayabileceği kısa cümleler ile başlanmalıdır. Zamanla bu cümleler sözcüklere, sözcükler hecelere bölünmelidir. Daha sonra heceler içindeki harflerin sesleri sezdirilmeye çalışılmalıdır. Bu cümleler sonunda elde edilen sözcük, hece ve sezilen harfler ile yeni cümle ve sözcükler oluşturulmalıdır. Cümlelerin, sözcüklerin ve hecelerin bölünmesini kolaylaştırmak için öğretmen ayn kelimeleri içine alan cümlelerden yararlanmalıdır. Okuma- yazma etkinlikleri her zaman birlikte yürütülmeli."(İlkokul Programı, 1968).

1968 ilköğretim programında yer alan cümle yöntemi ile ilk okuma ve yazma öğretimi yürütülürken Milli Eğitim Bakanlığı, yeni ilköğretim programını 2004-2005 eğitim-öğretim yılında pilot uygulayıp 2005-2006 eğitim-öğretim yılında ise ülkemiz genelinde uygulamaya koymuştur.

Söz konusu 2005 İlköğretim Programında,yapılandırıcı yaklaşım, çoklu zekâ, beyin temelli öğrenme, öğrenci merkezli eğitim, bireysel farklılıklara duyarlı eğitim, sarmal, tematik ve beceri yaklaşımı gibi yaklaşım ve modeller çerçevesinde geliştirilen Türkçe Dersi Öğretim Programı'nda ilk okuma-yazma öğretimi, Türkçe öğretiminin; dinleme, konuşma, okuma, yazma ve görsel okuma - görsel sunu öğrenme alanları ile birlikte ele alınmış, yöntem olarak Ses Temelli Cümle Yöntemi'nin kullanılması ön görülmüştür.

Programı'nda Ses Temelli Cümle Yöntemi'nin özellikleri, ilkeleri, aşamaları, uygulanması ve bitişik eğik yazıya ilişkin bilgiler verilmektedir.

Ses temelli cümle yönteminde, ilk okuma-yazma öğretimine seslerle başlanmaktadır. Anlamlı bütün oluşturacak birkaç ses verildikten sonra seslerden hecelere, kelimelere ve cümlelere ulaşılmaktadır. İlk okumayazma öğretimi, kısa sürede cümlelere ulaşılacak şekilde düzenlenmektedir. Yazı öğretiminde, öğrencilerin gelişimine uygun olan bitişik eğik yazı harfleri kullanılmaktadır (İlköğretim Programı, 2009).

Seslerin/harflerin öğretiminde alfabedeki sıralama değil, Türkçenin ses yapısı, harflerin yazım kolaylığı, anlamlı hece ve kelime üretmedeki işleklik dikkate alınarak oluşturulan altı grupta sıralanan ses/harflerin 
öğretimi, yöntemin aşağıda belirtilen aşamalarına uygun olarak gerçekleştirilir:

1. İlk okuma-yazmaya hazırlık

2. İlk okuma-yazmaya başlama ve ilerleme:

- Sesi hissetme ve tanima

- Sesi /harfi okuma ve yazma

- Sesten/harften, heceler, hecelerden kelimeler, kelimelerden cümleler oluşturma

- Metin oluşturma

3. Okuryazarlığa ulaşma (İlköğretim Programı, 2009).

Millî Eğitim Bakanlığı, 2016-2017 eğitim öğretim yılından itibaren uygulanmak üzere 2015 yılında Türkçe dersi öğretim programında bir dizi değişikliğe gitti. İlk okuma-yazma öğretimine ilişkin yapılan değişiklikler öz olarak şunlardır:

- Beş öğrenme alanı; sözlü iletişim, okuma ve yazma şeklinde değiştirilmiştir.

- Ses temelli cümle yöntemi ile öğretim ve yöntemin aşamalarında değişikliğe gidilmeyip, ilk okuma- yazma öğretiminde kullanılan ses/harf grupları değiştirildi.

- Öğretimin bitişik eğik yazı ile yürütülmesine devam edilmesi öngörüldü ancak bazı harflerin yazma şekilleri değiştirildi (İlköğretim Programi, 2015).

Millı̂ Eğitim Bakanlığı, 2017 - 2018 eğitim öğretim yılından itibaren uygulanmak üzere yine önemli birçok değişikliğe gitti. İlk okuma-yazma öğretimine ilişkin yapılan değişiklikler öz olarak şunlardır:

- Üç öğrenme alanı; dinleme/izleme, konuşma, okuma ve yazma şeklinde değiştirilmiştir.

- Ses temelli cümle yöntemi ile öğretim yerine Türkçe Dersi Öğretim Programı'nın ilk okuma yazma öğretiminde "Ses Esaslı İlk Okuma Yazma Öğretimi" yaklaşımı benimsenmiştir.

- Öğretimin aşamalarında değişikliğe gidilmiştir. İlk okuma yazma sürecinde şu aşamalar izlenmelidir:

1) İlk okuma yazmaya hazırlık

a) Dinleme eğitimi çalışmaları

b) Parmak, el ve kol kaslarını geliştirme çalışmaları 
c) Boyama ve çizgi çalışmaları

d) 2) İlk okuma yazmaya başlama ve ilerleme

e) Sesi hissetme, tanıma ve ayırt etme

f) Harfi okuma ve yazma

g) Harflerden heceler, hecelerden kelimeler, kelimelerden cümleler oluşturma

h) Metin okuma

3) Bağımsız okuma ve yazma

- İlk okuma- yazma öğretiminde kullanılan ses/harf grupları değiştirildi (ses/harf grubu beşe indirildi).

- İlk okuma yazma öğretimi dik temel harf veya birleşik eğik harflerle gerçekleştirilebileceği hükmü programda yer aldı (İlköğretim Programı, 2018).

İlk okuma yazma öğretimindeki başarı veya başarısızlık üzerinde program, okul, çevre-aile, öğretmen vb. birçok paydaşın rolü vardır. Bunlardan biri ise ilk okuma yazma öğretiminde öğretmenin izlendiği yöntemdir. Şüphesiz ilk okuma-yazma ve bununla elde edilen, geliştirilen bilgi, beceriler bireyin tüm yaşantısında önemli yere sahiptir. $\mathrm{Bu}$ öneme sahip öğretimde başarısızlıktaki temel nedenlerden birinin de öğretmenin öğretimde uyguladığı yöntem-tekniklerdeki yanlışlık ve yetersizlikler olduğunu söyleyebiliriz. Bundan hareketle, ilk okuma yazma öğretiminde uygulanan yöntem ve teknikler üzerinde yapılmış ve yapılacak alan araştırmaları çok önemlidir. Ses temelli cümle yöntemi ile ilk okuma yazma öğrenen öğrencilerin başarı durumları ve dolayısıyla yöntemin uygulamadaki başarısını belirlemeye yönelik olan çalışmamız; ilk okuma-yazma öğretiminde yöntemin uygulama aşamalarında öğrencilerin başarı durumları, görülen yetersizlikler, nedenleri, nedenlerin etkilerinin belirlenmesi ve çözüme yönelik önerilerin saptanması ve böylece ses temelli cümle yönteminin alanda daha etkili ve verimli uygulanması bakımından büyük önem taşımaktadır.

$\mathrm{Bu}$ araştırmanın genel amacı birinci sınıf öğretmenlerinin ilk okumayazma öğretiminde izledikleri ses temelli cümle yönteminin etki ve verimine ilişkin görüşleri ile yöntemin öğretimindeki başarısını uygulama basamakları doğrultusunda belirlemek, genel olarak uygulama ve özel olarak da yöntemin uygulama basamaklarında, yönteme bağlı 
olumlu ve olumsuz yönleri tespit etmektir. Bu doğrultuda araştırmada şu sorulara cevap aranmıştır:

1. Birinci sınıf öğretmenlerinin kişisel ve mesleki özellikleri ile "Ses Temelli Cümle Yöntemi"ne ilişkin yeterlilikleri nelerdir?

2. Birinci sınıf öğretmenlerinin "Ses Temelli Cümle Yöntemi" ve yöntemle öğretim için öğretim programında yer alanlara, programın etkililiğine ilişkin görüşleri nelerdir?

3. İlk okuma-yazma öğretiminde öğrenciler, hangi aşamada zorlanmakta?

4. Süreç sonunda ortalama kaç öğrenci başarısız olmakta ve hangi aşamada daha çok başarısızlık göstermekte?

5. Birinci sınıf öğretmenleri öğretim sürecini; planlama, etkinlik, ölçme-değerlendirme ve uygulama açısından nasıl değerlendirmekte?

6. Birinci sınıf öğretmenlerinin bitişik eğik yazı ile öğretime ilişkin görüşleri nelerdir?

\section{Yöntem}

\section{Araştırma Modeli}

Nicel çalışmanın araştırma modeli olarak betimsel araştırma yaklaşımı kullanılmıştır. Çok sayıda değişken ile ilgilenildiği için birden fazla araştırma sorusunun olduğu betimsel araştırma, temel düzeydeki betimleme soruların içerir (Gliner, Morgan ve Leech, 2009). Betimsel araştırma modellerinde istatistiksel anlamlılık test edilmez ve çıkarımsal istatistiğe ihtiyaç duyulmaz.

\section{Evren - Örneklem}

Çalışmanın evreni, ilk okuma ve yazma öğretimini ses temelli cümle yöntemi ile yürüten sınıf öğretmenleri, örneklemi ise çalışmaya katılan,İstanbul ilinde MEB'e bağlı devlet okullarında görev yapmakta olan ve ilk okuma - yazma öğretimini ses temelli cümle yöntemi ile gerçekleştiren 332 sınıf öğretmenidir. Uygun örnekleme yöntemi (Gay, Mills ve Airasian, 2006) ile İstanbul ilindeki okullar taranmış ve ses temelli cümle yöntemi ile okuma - yazma öğretimini gerçekleştiren sınıf 
Ses Temelli Cümle Yönteminin İlk Okuma-Yazma Öğretimi Üzerindeki Başarısının Öğretmen Açısından Değerlendirilmesi

öğretmenlerine araştırmacı tarafından geliştirilen veri toplama aracı uygulanmiştır.

Araştırmaya katılan 332 sınıf öğretmenine ait tanımlayıcı istatistikler tablo 1'de verilmiştir.

Tablo 1. Araştırmaya Katılan Öğretmenleri Tanımlayıcı İstatistikler

\begin{tabular}{|c|c|c|c|}
\hline Değişkenler & & $\mathbf{N}$ & $\%$ \\
\hline \multirow[t]{2}{*}{ Cinsiyet } & Kadın & 204 & 61,4 \\
\hline & Erkek & 128 & 38,6 \\
\hline \multirow[t]{5}{*}{ Mezun Olduğu Okul } & Öğretmen Okulu & 14 & 4,2 \\
\hline & Eğitim Enstitüsü & 56 & 16,9 \\
\hline & Eğitim Yüksek Okulu & 49 & 14,8 \\
\hline & Eğitim Fakültesi & 138 & 41,6 \\
\hline & Diğer & 75 & 22,5 \\
\hline \multirow[t]{4}{*}{ Alınan Derece } & Ön lisans & 62 & 18,7 \\
\hline & Lisans & 191 & 57,5 \\
\hline & Yüksek lisans & 6 & 1,8 \\
\hline & Branş dişı lisans & 71 & 21,4 \\
\hline Mesleki & $5-9$ & 14 & 4,2 \\
\hline \multirow[t]{6}{*}{ Kidem } & $10-14$ & 73 & 22 \\
\hline & $15-19$ & 103 & 31 \\
\hline & $20-24$ & 48 & 14,5 \\
\hline & $25-30$ & 30 & 9 \\
\hline & $31-35$ & 50 & 15,1 \\
\hline & $36-40$ & 13 & 3,9 \\
\hline Birinci Sınıflarla Eğitim- & 1 & 2 & 0,6 \\
\hline \multirow[t]{9}{*}{ Öğretimi Yürütme Sayısı } & 2 & 36 & 10,8 \\
\hline & 3 & 74 & 22,3 \\
\hline & 4 & 68 & 20,5 \\
\hline & 5 & 56 & 16,9 \\
\hline & 6 & 31 & 9,3 \\
\hline & 7 & 20 & 6 \\
\hline & 8 & 15 & 4,5 \\
\hline & 9 & 11 & 3,3 \\
\hline & 10 ve üzeri & 18 & 5,4 \\
\hline Ses Temelli Cümle Yöntemi İle & 1 & 155 & 46,7 \\
\hline \multirow{4}{*}{ Okuma - Yazma Öğretim Sayısı } & 2 & 143 & 43,1 \\
\hline & 3 & 23 & 6,9 \\
\hline & 4 & 7 & 2,1 \\
\hline & 5 & 3 & 0,9 \\
\hline \multirow{3}{*}{$\begin{array}{l}\text { Görev Yapılan } \\
\text { Birinci Sinıfların } \\
\text { Sınıf Mevcudu }\end{array}$} & $30-35$ & 41 & 12,3 \\
\hline & $36-40$ & 51 & 15,4 \\
\hline & $41-45$ & 79 & 23,8 \\
\hline
\end{tabular}




\begin{tabular}{lccc}
\hline & $46-50$ & 79 & 23,8 \\
$51-55$ & 47 & 14,2 \\
$56-60$ & 19 & 5,7 \\
$61-65$ & 5 & 1,5 \\
& $66-70$ & 4 & 1,2 \\
& $71-76$ & 4 & 1,2 \\
\hline Hazırlayıcı Eğitim $^{*}$ & Evet & 208 & 62,7 \\
& Hayır & 124 & 37,3 \\
\hline
\end{tabular}

"Ses Temelli Cümle Yöntemi İle İlk Okuma - Yazma Öğretimi Hakkında Hazırlayıcı Ĕ̆itime Katılma Durumu

Tablo 1 incelendiğinde; araştırmaya katılan öğretmenlerin, $\% 61,4^{\prime}$ ünün kadın ve \%38,6'sının erkek olduğu görülmektedir.Katılımcların \%4,2'si öğretmen okulu, \%16,9'u eğitim enstitüsü, $\% 14,8$ 's1 eğitim yüksek okulu, \%41,6's1 eğitim fakültesi ve \%22,6's1 diğer okullardan mezun olmuştur. Katılımcıların \%18,7'si ön lisans; \%57,5'i lisans; \%1,8'i yüksek lisans ve \%21,4'ü branş dışı lisans programından mezundur. Katılımciların; \%4,2'si 5-9 y1l, \%22'si 10-14 yıl, \%31'i 15-19 yıl, \%14,5'i 20-24 yıl, \%9'u 25-30 yıl, \%15,1'i 31-35 yıl ve \%3,9'u 36-40 yıl sinıf öğretmeni olarak görev yapmıştır. Katılımcıların; \%0,6'sı 1 yıl, $\% 10,8^{\prime}$ i 2 yıl, \%22,3'ü 3 yıl, \%20,5'i 4 yıl, \%16,9'u 5 yıl, \%9,3'üu 6 yıl, \%6'sı 7 yıl, \%4,5'i 8 yıl \%3,3'ü 9 yıl ve \%5,4'ü 10 ve üzeri yıl birinci sinıfta eğitim-öğretimi yürütmüştür. Katılımcıların \%46,7'si 1 defa, \%43,1'i 2 defa, $\% 6,9^{\prime}$ u 3 defa, \%2,1'i 4 defa ve $\% 0,9^{\prime}$ u 5 defa ses temelli cümle yönetimi ile okuma yazma öğretimini gerçekleştirmiştir. Katılımcılar, birinci sınıflarda eğitim - öğretimi yürüttükleri dönemlerde sınıf mevcutlarının, \%12,3'ünün 30-35 öğrenci, \%15,4'ünün 36-40öğrenci,\%23,8'i 4145öğrenci,\%23,8'inin 46-50öğrenci, \%14,2'sinin 51-55öğrenci, $\% 5,7^{\prime} \operatorname{sinin}$ 56-60öğrenci, \%1,5'inin 61-65 öğrenci,\%1,2'sinin 66-70 öğrenci ve $\% 1,2$ 'sinin 71-76 öğrenci olduğunu belirtmişlerdir.Katılımcıların \%62,7'si ses temelli cümle yöntemi ile ilk okuma - yazma öğretimine ilişkin hazırlayıcı eğitime katılırken \%37,3'ü böyle bir çalışmaya katılmadığını belirtmiştir.

\section{Veri Toplama Aracı}

Veri toplama aracı, kişisel ve mesleki bilgilere dair 10 soru ve İlköğretim Programı (2005) ve ses temelli cümle yöntemine dair 15 soru içermekte- 
dir. 1'i araştırmacı olmak üzere toplam 3 uzman görüşü alınarak hazırlanan ve betimsel soruların yer aldığı anket 30 öğretmene pilot olarak uygulanmıştır. Bu uygulama sonucunda 5 soru yeniden gözden geçirilmiş ve son halini almıştır.

\section{Verilerin Toplanması}

Verilerin toplanması aşamasında İstanbul ilinde bulunan ilkokullardan öncelikli olarak kolay ulaşılabilir olanlara gidilmiş ve veri toplama aracı,birinci sınıfta ses temelli cümle yöntemi ile okuma - yazma öğretimini yürütmüş sınıf öğretmenlerine, araştırmacı tarafından uygulanmıştır.

\section{Verilerinin Analizi}

Betimsel soruların yer aldığı veri toplama aracı ile elde edilen verilerin analizinde, frekans ve yüzde gibi tanımlayıcı istatistiklere yer verilmiştir. Araştırmanın amacına uygun olan sorularda ise daha detaylı bilgi edinmek için çapraz tablolama analizlerinden ki - kare istatistiğinden yararlanılmıştır.

\section{Bulgu}

Bu bölümde, araştırmanın bulgularına yer verilmiştir.

Ses temelli cümle yöntemine ilişkin İlköğretim Program'ındaki açıklamaları yeterli-yetersiz bulan katılımcılar tablo 2' de yer almaktadır.

Tablo 2. Ses Temelli Cümle Yöntemi ile İlk Okuma - Yazma Öğretimine İlişkin İlköğretim Programında Yer Alan Açıklamaları Yeterli - Yetersiz Bulma

\begin{tabular}{lcc}
\hline Seçenekler & $\mathbf{n}$ & $\mathbf{\%}$ \\
\hline Yeterli & 88 & 26,5 \\
Yetersiz & 244 & 73,5 \\
\hline
\end{tabular}

İlköğretim programında ses temelli cümle yöntemi ile ilk okuma yazma öğretimine ilişkin yer alan açıklamaları katılımcıların \%26,5'i yeterli ve $\% 73,5^{\prime}$ i yetersiz bulmuştur. 
Ses temelli cümle yöntemi ile öğretime ilişkin, öğretim programında (2005) yer alan açıklamaları yeterli bulmayan $244(\% 73,5)$ katılımcı öğretmenler, yetersiz buldukları yönleri önem derecesine göre (1.en önemli-5.daha az önemli) değerlendirilip sıralamışlardır. Önem derecesine göre yapılan siralama tablo 3'te yer almaktadır.

Tablo 3: İlköğretim Programının (2005) Yetersiz Görülen Yönlerinin Önem Derecesine Göre Stralanışının Betimleyici İstatistikleri

\begin{tabular}{|c|c|c|c|c|c|c|c|}
\hline & 1. & 2. & 3. & 4. & 5. & $\bar{X}$ & $\mathrm{n}$ \\
\hline \multicolumn{8}{|l|}{ Başlıklar } \\
\hline $\begin{array}{l}\text { Yöntem ve uygulama basamaklarına ilişkin } \\
\text { açıklamalar }\end{array}$ & 88 & 44 & 34 & 6 & 2 & 1,79 & 174 \\
\hline Ölçme ve değerlendirme & 30 & 41 & 44 & 22 & 13 & 2,65 & 150 \\
\hline Uygulama örnekleri & 63 & 80 & 33 & 9 & 4 & 2 & 189 \\
\hline Materyaller, nitelikleri ve kullanımı & 19 & 30 & 41 & 23 & 9 & 2,78 & 122 \\
\hline Yazı & 48 & 48 & 45 & 21 & 4 & 2,31 & 166 \\
\hline Diğer & 2 & 5 & 1 & 1 & 3 & 2,83 & 12 \\
\hline
\end{tabular}

Tablo 3'e göre; 174 öğretmenden 88'i yöntem ve uygulama basamaklarına ilişkin açıklamaları en önemli yetersizlik olarak belirtmiştir. 150 öğretmenlerden 30'u ölçme ve değerlendirme, 189 öğretmenden 60'1 uygulama örnekleri, 122 öğretmenden 27 'si materyal nitelikleri ve materyal kullanımına ilişkin, 166 öğretmenden $48^{\prime} i$ ise yazıya ilişkin açıklama ve hususları en önemli yetersizlik olarak belirtmiştir. Önemliden daha az önemliye doğru, katılımcların belirttikleri diğer açıklama ve yetersizlik sıralaması tabloda belirtilmiştir.

Tablo 4. Öğretmenlerin Öğretim Programında Ses Temelli Cümle Yöntemi ile İlk Okuma -Yazma Öğretim Sürecinde Karşılaştıkları Soru-Sorunlara Çözüm ve Yeterli Uygulama Örnekleri Bulması

\begin{tabular}{lcc}
\hline & $\mathbf{n}$ & $\mathbf{\%}$ \\
\hline Süreçte karşılaştığınız soru/sorularınıza bu programda çözüm bulabiliyor muydunuz? \\
\hline Evet & 81 & 24,4 \\
Hayır & 63 & 19 \\
Kısmen & 188 & 56,6 \\
\hline Uygulamaya dair yeterli örnekler bulabildiniz mi? & & \\
\hline Evet & 106 & 31,9 \\
Hayır & 55 & 16,6 \\
Kısmen & 171 & 51,5 \\
\hline
\end{tabular}


Tablo 4'e göre ses temelli cümle yöntemi ile ilk okuma - yazma öğretimi sürecinde, katılımcıların \%24,4'ü karşılaştıkları soru ve sorunlarına İlköğretim Programında çözüm bulabildiklerini, \%19'u bulamadıklarını ve \%56,6'sı ise kısmen bulabildikleri belirtmişlerdir. Uygulamaya dair yeterli örnekler bulabildiniz mi sorusuna ise \%31,9'u evet, $\% 16,6$ 'sı hayır ve \%51,5'i kısmen cevabını vermiştir.

Tablo 5. Ses Temelli Cümle Yöntemi ile İlk Okuma - Yazma Öğretiminde Öğrencilerin Zorlandıklarn Aşama, Başarısız Öğrenci ve En Çok Başarısızlık Görülen Aşama

\begin{tabular}{lcc}
\hline & $\mathbf{n}$ & $\mathbf{\%}$ \\
\hline Öğretimde öğrenciler genel olarak hangi aşamada zorlanmaktadır? & 37 & 11,1 \\
\hline Hazırlı & 52 & 15,7 \\
Sesi Hissetme Tanıma & 52 & 15,7 \\
Sesi Okuma - Yazma & 88 & 26,6 \\
Hece Oluşturma & 39 & 11,8 \\
Kelime Oluşturma & 20 & 6 \\
Cümle Oluşturma & 21 & 6,3 \\
Metin Oluşturma & 22 & 6,6 \\
Okuryazarlığa Ulaşma & 262 & 80,6 \\
\hline Gerekli kazanımları gösteremeyen genel olarak başarısız olan ortalama kaç öğrenciniz oldu? & 14,2 \\
\hline 1-3 & 46 & 3,1 \\
4-6 & 10 & 2,2 \\
7 - 9 & 7 & \\
10 ve üzeri & 76,5 \\
\hline Başarısız öğrenciler ilk okuma - yazma öğreniminin en çok hangi aşamasında yetersizlik \\
göstermiştir? & & \\
\hline Hazırlık & 21 & 17,6 \\
Sesi Hissetme Tanıma & 57 & 18,5 \\
Sesi Okuma - Yazma & 60 & 33,3 \\
Hece Oluşturma & 108 & 8 \\
Kelime Oluşturma & 26 & 4,6 \\
Cümle Oluşturma & 15 & 1,9 \\
Metin Oluşturma & 6 & 9,6 \\
Okuryazarlığa Ulaşma & 31 &
\end{tabular}

Tablo 5'e göre,ses temelli cümle yöntemi ile ilk okuma - yazma öğretimi sürecinde öğrenciler genel olarak hangi aşamada zorlanmaktadır sorusuna katılımciların \%11,1'i hazırlık, \%15,7'si sesi hissetme, tanıma, \%15,7'si sesi okuma - yazma, \%26,6'si hece oluşturma, \%11,8'i kelime oluşturma, \%6'sı cümle oluşturma, \%6,3'ü metin oluşturma ve $\% 6,6$ 'sı okuryazarlığa ulaşma şeklinde cevap vermişlerdir. Süreç sonunda gerekli kazanımları gösteremeyen ve genel olarak başarısız olan 
ortalama kaç öğrenciniz oldu sorusuna katılımcıların \%80,6'sı 1-3, $\% 14,2$ 'si 4-6, \%3,1'i 7-9 ve \%2,2'si ise 10 ve üzeri cevaplarını vermiştir. Başarısız öğrenciler ilk okuma - yazma öğretiminin en çok hangi aşamasında yetersizlik göstermiştir sorusuna ise katılımcıların \%6,5'i hazırlık, \%17,6'sı sesi hissetme, tanıma, \%18,5'i sesi okuma - yazma, $\% 33,3$ 'ü hece oluşturma, \%8'i kelime oluşturma, \%4,6's1 cümle oluşturma, \%1,9'u metin oluşturma ve \%9,6'sı okuryazarlığa ulaşma şeklinde belirtmişlerdir.

Tablo 6. Ses Temelli Cümle Yöntemi ile İlk Okuma - Yazma Öğretimini; Planlama, Etkinlikler ve Uygulama Açılarından Değerlendirme

\begin{tabular}{lcccccccccccc}
\hline & \multicolumn{1}{c}{ Kolay } & \multicolumn{2}{c}{ Zor } & \multicolumn{2}{c}{ Basit } & Karmaşık & Kisa süre & \multicolumn{2}{c}{$\begin{array}{c}\text { Uzun } \\
\text { süre }\end{array}$} \\
\hline Seçenekler & $\mathbf{n}$ & $\mathbf{\%}$ & $\mathbf{n}$ & $\mathbf{\%}$ & $\mathbf{n}$ & $\mathbf{\%}$ & $\mathbf{n}$ & $\mathbf{\%}$ & $\mathbf{n}$ & $\mathbf{\%}$ & $\mathbf{n}$ & $\mathbf{\%}$ \\
\hline Planlama & 254 & 76,7 & 77 & 23,3 & 227 & 69,2 & 101 & 30,8 & 244 & 73,5 & 84 & 25,3 \\
Etkinlikler & 176 & 53,8 & 151 & 46,2 & 146 & 44,6 & 181 & 55,4 & 118 & 36 & 210 & 64 \\
Ölçme ve & 210 & 63,4 & 121 & 36,6 & 188 & 57,3 & 140 & 42,7 & 166 & 50,5 & 163 & 49,5 \\
$\begin{array}{l}\text { Değerlendirme } \\
\text { Uygulama }\end{array}$ & 129 & 39,3 & 199 & 60,7 & 118 & 35,8 & 212 & 64,2 & 118 & 35,8 & 212 & 64,2 \\
\hline
\end{tabular}

Ses temelli cümle yöntemi ile ilk okuma - yazma öğretiminde planlamayı katılımcların \%76,7'si kolay ve \%23,3'ü zor, \%69,2'si basit ve \%30,8'i karmaşık, \%73,5'i kısa süreli ve \%25,3'ü uzun süreli olarak nitelendirmiştir. Etkinlikleri, katılımcıların $\% 53,8$ i kolay ve $\% 46,2$ 'si zor, $\% 44,6$ 'sı basit ve $\% 55,4^{\prime}$ ü karmaşık, \%36's1 kısa süreli ve $\% 64$ 'ü uzun süreli olarak nitelendirmiştir. Ölçme ve değerlendirme için katılımcların $\% 63,4^{\prime}$ ü kolay ve \%36,6'sı zor, \%57,3'ü basit ve \%42,7'si karmaşık, $\% 50,5$ 'i kısa süreli ve $\% 49,5$ 'i uzun süreli olarak nitelendirmiştir. Uygulama için katılımcların \%39,3'ü kolay ve $\% 60,7^{\prime}$ si zor, $\% 35,8^{\prime} i$ basit ve \%64,2'si karmaşık, \%35,8'i kısa süreli ve \%64,2'si uzun süreli olarak nitelendirmiştir.

Tablo 7. Ses Temelli Cümle Yöntemi ile İlk Okuma - Yazma Öğretimi İçin Ön Görülen Süreci Bilgi, Becerilerin Kazanılması ve Nitelikli Okuma - Yazma Öğretimi İçin Yeterli Bulma - Bulmama

\begin{tabular}{lcc}
\hline Seçenekler & n & \% \\
\hline Evet & 213 & 64,4 \\
Hayır & 118 & 35,6 \\
\hline
\end{tabular}


Tablo 7'ye göre ses temelli cümle yöntemi ile okuma yazma öğretimi için ön görülen süre, bilgi, becerilerin kazanılması ve nitelikli okuma yazma öğretimi için yeterlimidir sorusuna, katılımcıların \%64,4 evet ve \%35,6 hayır cevaplarını verilmişlerdir.

Tablo 8. Ses Temelli Cümle Yöntemi ile İlk Okuma - Yazma Öğretiminde, Bitişik Eğik Yazı ile Yapılan Öğretimi Verimli - Başarılı Bulma

\begin{tabular}{lcc}
\hline Seçenekler & $\mathbf{n}$ & $\mathbf{\%}$ \\
\hline Evet & 39 & 11,7 \\
Hayır & 293 & 88,3 \\
\hline
\end{tabular}

Tablo 8'e göre ses temelli cümle yöntemi ile ilk okuma - yazma öğretiminde, bitişik eğik yazı yapılan öğretimi verimli, başarılı buluyor musunuz sorusuna katılımciların $\% 11,7$ evet ve $\% 88,3$ hayır cevaplarını verilmişlerdir.

Tablo 9. Ses Temelli Cümle Yöntemi ile İlk Okuma - Yazma Öğretimi, Bitiş̧ik Eğik Yazı ile Yapılan Öğretimde Tespit Edilen Yetersizliklerin Önem Derecesine Göre Değerlendirilmesi

\begin{tabular}{lccccccc}
\hline Başlıklar & $\mathbf{1 .}$ & $\mathbf{2 .}$ & $\mathbf{3 .}$ & $\mathbf{4 .}$ & $\mathbf{5 .}$ & $\overline{\boldsymbol{X}}$ & $\mathbf{n}$ \\
\hline Eğik yazamama & & & & & & & \\
Yazının okunamaması & 123 & 59 & 46 & 19 & 13 & 2,00 & 260 \\
Harfleri kurallarına uygun yazamama & 49 & 76 & 44 & 58 & 20 & 2,69 & 247 \\
Harfleri birleştirememe & 100 & 60 & 67 & 18 & 10 & 2,13 & 255 \\
Harf ve kelimeler arasında uygun mesafe bıraka- & 19 & 71 & 63 & 37 & 19 & 2,84 & 209 \\
mama & 15 & 35 & 24 & 56 & 3,91 & 131 \\
İmla ve noktalama problemleri & & & & & & & \\
Yazıyı satırda uygun aralıklarla yerleştirememe & 3 & 6 & 8 & 16 & 62 & 4,35 & 95 \\
Diğer & 6 & 14 & 23 & 23 & 61 & 3,94 & 127 \\
& - & - & - & 2 & 5 & 4,71 & 7 \\
\hline
\end{tabular}

Ses temelli cümle yöntemi ile ilk okuma - yazma öğretiminde, bitişik eğik yazı ile öğretimi verimli, başarılı bulmayan 293 (\%88,3) katılımcı öğretmenin cevapladığı soruda, yetersizliklerin önem derecesine göre (1.en önemli-5.daha az önemli) sıralanışı tabloda belirtilmiştir.Buna göre; 260 öğretmenden 123'ü eğik yazamama, 247 öğretmenden 49'u yazının okunamaması, 255 öğretmenden 100'ü harfleri kurallarına uygun yazamama, 209 öğretmenden 19'u harfleri birleştirememe, 131 öğretmenden 
1'i harf ve kelimeler arasında uygun mesafe bırakamama, 95 öğretmenden 3'ü imla ve noktalama problemlerini, 127 öğretmenden 6's1 yazıyı satırda uygun aralıklara yerleştirememe yetersizliklerini en önemli olarak belirtmişlerdir. Katılımcıların belirttiği olumsuzlukların daha az önem derecesine göre sıralanışı tabloda yer almıştır.

Tablo 10. Yazıdaki Verimsizlik ve Başarısızlık Sebeplerinin Önem Derecesine Göre Stralanışı

\begin{tabular}{|c|c|c|c|c|c|c|c|}
\hline & 1. & 2. & 3. & 4. & 5. & $\overline{\boldsymbol{X}}$ & n \\
\hline \multicolumn{8}{|l|}{ Başlıklar } \\
\hline $\begin{array}{l}\text { Yazıya yönelik programda yer alan açıklama ve } \\
\text { uygulama örneklerindeki yetersizlik }\end{array}$ & 46 & 29 & 23 & 19 & 11 & 2,38 & 128 \\
\hline Çocukların gelişim özellikleri & 144 & 46 & 33 & 13 & 4 & 1,70 & 240 \\
\hline $\begin{array}{l}\text { Seçilen ve kullanılan materyaller ile bunların } \\
\text { niteliği }\end{array}$ & 10 & 30 & 26 & 18 & 22 & 3,11 & 106 \\
\hline Öğretim için ayrılan sürenin yetersizliği & 12 & 32 & 33 & 19 & 26 & 3,12 & 122 \\
\hline Sinıfın kalabalık olması & 49 & 89 & 55 & 16 & 11 & 2,32 & 220 \\
\hline Aile ve çalışma ortamı & 36 & 69 & 78 & 27 & 19 & 2,67 & 229 \\
\hline Diğer & 3 & 2 & 6 & 1 & 6 & 3,28 & 18 \\
\hline
\end{tabular}

Ses temelli cümle yöntemi ile ilk okuma - yazma öğretiminde, bitişik eğik yazı ile öğretimi verimli, başarılı bulmayanların (\%88,3) cevapladığı soruda verimsizlik, başarısızlık sebepleri katılımcılar tarafından önem derecesine göre (1.en önemli-5.daha az önemli) sıralanmıştır. Buna göre,128 katılımcı öğretmenden 46 'sı yazıya yönelik programda yer alan açıklama ve uygulama örneklerindeki yetersizlikleri, 240 öğretmenden 144'ü çocukların gelişim özelliklerini, 106 öğretmenden 10'u seçilen ve kullanılan materyaller ile bunların niteliğini, 122 öğretmenden 12 'siöğretim için ayrılan sürenin yetersizliğini, 220 öğretmenden $49^{\prime} u$ sınıfın kalabalık olmasını, 229 öğretmenden 36'sı aile ve çalışma ortamını, 18 öğretmenden 3 'ü ise diğerini yazıdaki verimsizlik ve başarısızlık sebebi olarak belirtmiştir. Yazıda başarısızlık ve verimsizlik sebeplerine ilişkin önemliden daha az önemliye doğru yapılan diğer sıralaması tabloda belirtilmiştir. 
Ses Temelli Cümle Yönteminin İlk Okuma-Yazma Öğretimi Üzerindeki Başarısının Öğretmen Açısından Değerlendirilmesi

Tablo 11. Ses Temelli Cümle Yöntemi ile İlk Okuma - Yazma Öğretiminde Öğrencilerin Zorlandıkları Aşamaların Öğrencilerin Yetersizlik Gösterdikleri Alana Göre Analizi

\begin{tabular}{|c|c|c|c|c|c|c|c|c|c|c|c|}
\hline & $\begin{array}{l}\mathbf{1} \\
\mathbf{n}\end{array}$ & $\begin{array}{l}2 \\
\mathrm{n}\end{array}$ & $\begin{array}{l}3 \\
\mathrm{n}\end{array}$ & $\begin{array}{l}4 \\
\mathrm{n}\end{array}$ & $\begin{array}{l}5 \\
\mathbf{n}\end{array}$ & $\begin{array}{l}6 \\
\mathrm{n}\end{array}$ & $\begin{array}{l}7 \\
\mathbf{n}\end{array}$ & $\begin{array}{l}8 \\
\mathrm{n}\end{array}$ & $\chi^{2}$ & sd & $p$ \\
\hline Hazırlik $^{1}$ & 14 & 3 & 5 & 9 & 2 & - & 0 & 4 & 322,10 & 49 & $0,00^{*}$ \\
\hline $\begin{array}{ll}\text { Sesi } & \text { Hissetme, } \\
\text { Tanımı }{ }^{2} & \end{array}$ & 2 & 29 & 7 & 8 & 1 & 1 & 0 & 4 & & & \\
\hline Sesi Okuma Yazma ${ }^{3}$ & - & 7 & 23 & 15 & 1 & - & 1 & 4 & & & \\
\hline Hece Oluşturma $^{4}$ & 3 & 8 & 5 & 53 & 5 & 3 & - & $6-$ & & & \\
\hline Kelime Oluştuma ${ }^{5}$ & 1 & 5 & 9 & 9 & 13 & - & - & 2 & & & \\
\hline Cümle Oluşturma ${ }^{6}$ & - & 2 & 5 & 4 & 1 & 7 & - & - & & & \\
\hline Metin Oluşturma7 & - & 3 & 3 & 5 & 2 & 2 & 3 & 2 & & & \\
\hline $\begin{array}{l}\text { Okuryazarlığa } \\
\text { Ulaşma }^{8}\end{array}$ & 1 & 0 & 3 & 5 & 1 & 2 & 1 & 9 & & & \\
\hline Toplam & 21 & 57 & 60 & 108 & 26 & 15 & 5 & 31 & & & \\
\hline
\end{tabular}

Tablo 11'e göre, "ses temelli cümle yöntemi ile yürüttüğünüz ilk okuma - yazma öğretimi süreci sonunda öğrenciler genel olarak hangi aşamada zorlanmaktaydı?" sorusuna katılımcıların verdikleri cevaplar ile katılımcılar tarafından, öğrencilerin ilk okuma - yazma öğretiminde yetersizlik gösterdikleri alanlar için belirtilenler arasında anlamlı bir fark bulunmuştur $\left(\chi^{2}(49)=322,10 ; p<0,001\right)$.

\section{Tartışma, Sonuç ve Öneriler}

Araştırmanın genel amacı doğrultusunda belirlenmiş olan sorulara ilişkin verilerin analizi sonucunda ortaya konan bulgulardan hareketle aşağıdaki sonuçlara ulaşılmış ve bu doğrultuda öneriler getirilmiştir.

Araştırmaya katılan öğretmenlerin kişisel bilgilerine göre katılımcıların \%61,4'ünün kadın ve \%38,6'sının erkektir. Katılımcıların; $\% 77,5$ 'nin öğretmen yetiştiren kurumdan sınıf öğretmeni olarak mezun olduğu, \%22,5'nin ise branş dişından bir lisans programından mezun olup sinıf öğretmenliği formasyonu alarak sınıf öğretmeni olarak görev yaptığı, \%78,9'nun en az lisans derecesine sahip olduğu, \%73,5'nin 15 yıl üstü mesleki kıdeme sahip olduğu, $\% 88,6$ 'sının 3 yıl/defadan fazla birinci sinıflarda eğitim-öğretimi yürüttüğü, $\% 9,9^{\prime}$ nun ses temelli cümle yöntemi ile ilk okuma-yazma öğretimini 3-5 defa gerçekleştirdiği, \%51,5'nin 
birinci sınıflarda eğitim öğretimi yürütürken sınıf mevcutlarının 45 öğrencin altında olduğu ve \%62,7'sinin ses temelli cümle yöntemi ile ilk okuma-yazma öğretimine ilişkin hazırlayıcı eğitime katıldığı görülmektedir. Çalışmamız bulgularını ile benzerlik gösteren Aktürk ve Mentiş Taş (2011) araştırmasında,araştırmaya katılan öğretmenlerin yarısından fazlası $(\% 61,2)$ ses temelli cümle yöntemine ilişkin, kılavuz kitaplardan, internetten, kursa katılarak, deneyimli öğretmenlerden yararlanarak yeterli bilgiye sahip olduklarını belirtmişlerdir. Öğretmenlerin $\% 38,8$ 'i ise yeterli bilgiye sahip olmadıklarını belirtmişlerdir.

$\mathrm{Bu}$ bulgular doğrultusunda kısaca şunları ifade etmemiz mümkündür:

1. Birçok çalışmada olduğu gibi öğretmenlerin hele hele sınıf öğretmenlerinin önemli kısmı kadındır. Zira yapılan çalışmalara bakıldığında, katılımcı öğretmenlerin büyük çoğunluğu kadındır. Tok, Türkay, Tok ve Mazı, 2008; Akman ve Aşkın 2012; Yılmaz, 2009 vb. bir çok çalışmada görülebileceği gibi. Yani bilindiği ve görüldüğü gibi öğretmenlik daha çok kadınların tercih ettikleri meslektir ve olmaya da devam edecektir diyebiliriz.

2. Çalışmaya katılan öğretmenlerin çok önemli kısmı sınıf öğretmenliği programından ve lisans derecesine sahiptir. Yani, branşı sinıf öğretmeni olmayan ve sonradan formasyon alarak sinıfın öğretmeni olarak görev yapanların oranı düşüktür $(\% 22,5)$. Ancak, bu oran branşı sınıf öğretmeni olanlar içinde yinde oldukça yüksektir. Zira bu durumun, başarı ve nitelikliğin yüksek veya düşük olması ile ilişkili olduğunu düşündürmektedir.

3. Katılımcıların çok önemli kısmı yüksek mesleki kıdeme ve biri sinıflarda eğitim-öğretim tecrübesine sahiptir. \%62,7'si ise ses temelli cümle yöntemi ile ilk okuma-yazma öğretimine ilişkin hazırlayıcı eğitime katıldığını belirtmiştir. Bu verilerden hareketle, araştırmamızın oldukça güvenilir olduğunu söylememiz mümkündür.

4. Katılımcıların yüksek mesleki kıdeme ve birinci sınıflarda eğitim-öğretim tecrübesine sahip olmalarına rağmen ancak \%9,9'u 3-5 defa ses temelli cümle yöntemi ile ilk okuma - yazma öğretimini gerçekleştirmiştir. Katılımcıların \%89,8'i ise 1-2 defa 
ses temelli cümle yöntemi ile ilk okuma - yazma öğretimini yürütmüştür. Bunu sebebinin, ses temelli cümle yönteminin ve bu yöntem ile ilk okuma-yazma öğretiminin oldukça yeni yani, 2005 ilkokul programında yer alıp uygulamaya geçilmesinin olduğunu söyleyebiliriz.

5. Katılımcıların \%47,6's1 gibi önemli kısmı, birinci sınıflarda eğitim-öğretimi yürüttükleri dönemlerde sınıf mevcutlarının ortalama 46-50 ve üstünde öğrenci olduğunu belirtmişlerdir. Bu durum gerekli kazanımları gösteremeyen genel olarak başarısız olan öğrenci sayısının yüksek olmasının (öğretmenlerin \%80,6's1, ortalama 1-3 başarısız öğrencileri olduğunu belirtmiştir) temel nedeni olarak değerlendirilebilir.

Ses temelli cümle yöntemi ile ilk okuma - yazma öğretimine ilişkin ilköğretim programında (2005) yer alan açıklamaları katılımcıların $\% 26,5$ 'i yeterli görürken $\% 73,5$ 'i gibi önemli kısmı yetersiz bulmuştur. Katılımcıların \%62,7'sinin ses temelli cümle yöntemi ile ilk okumayazma öğretimine ilişkin hazırlayıcı eğitime katılma nedenlerinden birinin de, ilköğretim programında ilk okuma - yazma öğretimine ve öğretim yöntemine ilişkin açılamaların yeterli olmamasıdır denilebilir. Nitekim,katılımcılardan programı yetersiz görenlerin, yetersiz gördükleri hususları önem derecesine göre en önemliden daha az önemliye doğru dereceli sıralamaları istemiştir. Programdaki ilgili açıklamaları yetersiz bulan; 174 öğretmenden $88^{\prime} \mathrm{i}$ yöntem ve uygulama basamaklarına ilişkin açıklamaları, 189 öğretmenden 63 uygulama örnekleri, 166 öğretmenden 48 'i yazı ve 150 öğretmenden 30'u ölçme ve değerlendirme ile ilgili açıklamaları en önemli yetersizlik olarak belirtmiştir. Sonra belirtilen önemli yetersizlikler ise 189 öğretmenden 80'nin belirttiği uygulama örnekleri, 174 öğretmenden 44'ünün belirttiği yöntem ve uygulama basamaklarına ilişkin açılamalar ve 166 öğretmenden 48'inin belirttiği yazı ile ilgili yetersizliklerdir.

Katılımcıların, öğretim programını (2005), ses temelli cümle yöntemi ile ilk okuma - yazma öğretim sürecinde karşılaştıkları soru-sorunlara çözüm ve yeterli uygulama örnekleri bulmaları ile ilgili olarak değerlendirmeleri istenmiştir. Katılımcıların \%24,4'i evet, karşılaştığım soru/sorulara çözüm bulabiliyorum, \%19'u bulamıyorum ve \%56,6 gibi önemli kısmı ise kısmen bulabiliyorum cevaplarını vermişlerdir. Uygu- 
lamaya dair yeterli örnekler bulabildiniz mi sorusuna ise katılımcıların $\% 31,9^{\prime}$ u evet, \%16,6'sı hayır ve \%51,5'i kısmen cevabını vermiştir. Bu bulgulardan hareketle katılımcların büyük çoğunluğunun, programın özellikle yöntemin basamakları ile ilgili açıklamalar, uygulama örnekleri ve yazı konusunda yetersiz olduğunu ve uygulamada karşılaştıkları soru ve sorunlara programdan çözüm üretemediklerini ifade edebiliriz. Beyazıt (2008) tarafından yapılan ve araştırma bulgularımızı destekleyen çalışmada; öğretmenlerin ilk okuma ve yazma yöntemi ile ilgili yeterince bilgilendirilmemeleri sebebiyle uygulama aşamasında sorunlar yaşadığı belirtilmiştir.

Ses temelli cümle yöntemi ile ilk okuma - yazma öğretimi sürecinde öğrenciler genel olarak hangi aşamada zorlanmaktadır sorusuna katılımcıların \%26,6'sı hece aşamasını belirtirken \%15,7'si sesi hissetme tanıma ve sesi okuma-yazma ve $\% 11,8^{\prime} i$ ise kelime oluşturma aşamasını belirtmiştir. Bu oran ve aşama genel olarak beklenendir. Zira bu aşama, her yöntem için aynı özellikleri göstermektedir diyebiliriz. Bunun önemli nedeninin ise bu aşamada, hele hele analiz grubu yöntemlerde öğretimin soyutlaşıp öğrenci için iyiden iyiye anlamsızlaşmasının olduğunu söyleyebiliriz. Nitekim, Avcı ve Şahin tarafından yapılan ve araştırma bulgularımızı destekleyen çalışmada, görüşme yapılan öğretmenlerin tümüne yakını ses temelli cümle yöntemi ile okuma yazma öğretiminde değişik birçok problemle karşılaştıklarını belirtmişlerdir. Bu problemlerin; öğrencilerin okuduğunu anlamama, harflerin seslerini yanlış çıkarmalarından kaynaklı yanlış okumalar, iki sesi birleştirirken ayrı ayrı okuyup sesleri birleştirememe ile ilgilidir (Avcı ve Şahin, 2016).

Öğretim süreci sonunda gerekli kazanımları gösteremeyen ve genel olarak başarısız olan ortalama kaç öğrenciniz oldu sorusuna, katılımcıların \%80,6'1 gibi büyük kısmı 1-3 öğrenci cevabını vermiştir. Katılımcılar tarafından, ilk okuma-yazma öğretim süreci sonunda başarısız olan öğrenci sayısının bu kadar düşük belirtilmesinin ve olmasının sebebinin; kurumlar yönetmeliğinin sınıf geçme-kalma konusundaki hükmünün ve konuya oldukça duygusal yaklaşan öğretmenlerin, sınıflarında başarısız olan öğrenci sayılarını belirtmek istememelerinin olduğunu belirtmemiz mümkündür. Başarısız öğrenciler, ilk okuma - yazma öğreniminin en çok hangi aşamasında yetersizlik göstermiştir sorusuna ise katılımcıların \%33,3 gibi önemli kısmı hece 
aşaması, \%18,5'i sesi okuma-yazma ve \%17,6's1 ise sesi hissetme tanıma cevabını vermiştir.

Ses temelli cümle yöntemi ile ilk okuma - yazma öğretiminde planlamayı katılımciların \%76,7'si kolay ve \%23,3'ü zor, \%69,2'si basit ve \%30,8'i karmaşık, \%73,5'i kısa süreli ve \%25,3'ü uzun süreli olarak nitelendirmiştir. Etkinlikleri, katılımcıların $\% 53,8$ i kolay ve $\% 46,2$ 'si zor, $\% 44,6^{\prime}$ sı basit ve $\% 55,4^{\prime}$ ü karmaşık, \%36'sı kısa süreli ve \%64'ü uzun süreli olarak nitelendirmiştir. Ölçme ve değerlendirme için katılımcların $\% 63,4^{\prime}$ ü kolay ve $\% 36,6$ 's1 zor, $\% 57,3^{\prime}$ ü basit ve \%42,7'si karmaşık, $\% 50,5$ 'i kısa süreli ve \%49,5'i uzun süreli olarak nitelendirmiştir. Uygulama için katılımcıların \%39,3'ü kolay ve \%60,7'si zor, \%35,8'i basit ve $\% 64,2^{\prime}$ si karmaşık, \%35,8'i kısa süreli ve $\% 64,2^{\prime}$ si uzun süreli olarak nitelendirmiştir. Akıncı, Bektaş, Gülle, Kurt ve Kurt (2016) tarafından gerçekleştirilen çalışmada öğretmenler, ilk okuma yazma öğretiminde, ses temelli cümle yöntemi ile cümle yöntemini kıyasladıklarında, ses temelli cümle yönteminin kendileri için öğretimi kolaylaştırdığını belirtmişlerdir.

Ses temelli cümle yöntemi ile okuma yazma öğretiminde gerekli bilgi, becerilerin kazanılması ve nitelikli okuma yazma öğretimi için ön görülen süreyi, katılımcıların $\% 64,4^{\prime}$ i yeterli, $\% 35,6$ 's1 ise yetersiz bulmuştur. Şahin vd. (2005) tarafından yapılan ve araştırma bulgularımızı destekleyen çalışmada, katılımcılar ilk okuma-yazma öğretim sürecini yeterli görmüştür.

Ses temelli cümle yöntemi ile ilk okuma - yazma öğretiminde, bitişik eğik yazı ile yapılan öğretimi öğretmenlerin \%11,7'si başarılı bulurken \%88,3'ü gibi önemli kısmı ise başarısız bulmuştur. Bitişik eğik yazı ile yapılan öğretimi başarılı bulmayan 293 katılımcı öğretmenin (\%88,3) cevapladığ1 soruda; 260 öğretmenden 123'ü dik yazamama, 255 öğretmenden 100 'ü harfleri kurallarına uygun yazamama ve 247 öğretmenden 49'u ise yazının okunamamasını en önemli yetersizlik olarak belirtmiştir. Yine 247 öğretmenden 76'sı yazının okunamamasını, 209 öğretmenden 71'i harfleri birleştirememe, 255 öğretmenden 60'1 harfleri kurallarına uygun yazamama ve 260 öğretmenden $59^{\prime} u$ ise eğik yazamamayı ikinci dereceden yetersizlik olarak görmüştür. Kadıŏlu Ateş vd. (2014) tarafından gerçekleştirilen çalı̧̧mada da benzer bulgulara ulaşılmıştır. Zira çalışmaya katılan öğretmenlerin büyük çoğunluğu; yazıların oku- 
naksız olması, uzun kelimeler yazarken harf eksikliklerinin yapılması, bitişik eğik yazının okuldaki tüm öğrenciler ve öğretmenler tarafından kullanılmaması, harflerin eğik yazılamaması, harflerin bağlantılarının kuralına göre yazılamaması, bitişik eğik yazının yorucu olması, uzun kelimelerin zor yazılması, okuma ile yazmanın paralel gitmemesi, çocuğun yakın çevresinde bitişik eğik yazı örneklerinin olmaması, bitişik eğik yazının Türkçe'ye uygun olmaması, öğrencilerin yazılarının estetik olmaması, ailelerin çocuklarına düz yazı öğretmesi, öğrencilerin küçük kas becerilerinin yeterince gelişmemiş olması, öğrencilere bitişik eğik yazının sıkıcı gelmesi gibi nedenlerle bitişik eğik yazı öğretimini başarısız bulduklarını belirtmiştir. Şahin ve Akyol (2006) araştırmasında öğretmenler, yazı öğretiminde dik temel harfleri bitişik eğik yazı tekniğinden daha çok tercih ettiklerini saptamıştır. Yine, Aktürk ve Mentiş Taş (2011)araştırması sonucunda, öğretmenlerin bir kısmı (\%34,2) bitişik eğik yazı kullanımının yöntemin etkili ve verimli olmasını engellediğini, Arslan ve Ilgın (2010)'ın araştırmalarında ise öğretmenler, birinci sınıfta ilk okuma - yazma öğretimine dik temel harfler ile başlanması gerektiğini belirtmişlerdir.

Yine, ses temelli cümle yöntemi ile ilk okuma - yazma öğretiminde, bitişik eğik yazı ile öğretimi verimli, başarılı bulmayan katılımcların $(\% 88,3)$ cevapladığı soruda verimsizlik, başarısızlık sebepleri katılımcılar tarafından önem derecesine göre sıralanmıştır. Buna göre; 240 katılımcı öğretmenden 144'üçocukların gelişim özelliklerini, 220 öğretmenden 49'u sınıfın kalabalık olmasını, 128 öğretmenden 46'sı yazıya yönelik programda yer alan açıklama ve uygulama örneklerindeki yetersizlikleri, 229 öğretmenden 36'sı ise aile ve çalışma ortamını bitişik eğik yazıdaki en önemli verimsizlik ve başarısızlık sebebi olarak belirtirken 220 öğretmenden 89'u sınıfların kalabalık olmasını, 229 öğretmenden $69^{\prime} u$ aile ve çalışma ortamını, 240 öğretmenden 46'sı ise çocukların gelişim özelliklerini ikinci dereceden önemli başarısızlık ve verimsizlik sebebi olarak görmüştür. "Yazı öğretiminde, öğrencilerin gelişimine uygun olan bitişik eğik yazı harfleri kullanılmaktadır" (İlköğretim Programı, 2009) ifadesi, bitişik eğik yazının, çocukların gelişim özelliklerine uygun olduğunu ve öğretimde kullanılmasının gerekçesini ifade eder. Ancak, araştırmaya katılan ve bitişik eğik yazı ile öğretimi verimli, başarılı bulmayan katılımcı 240 öğretmenden 144'ü, yazıdaki verimsizlik başarısızlık se- 
beplerinin en önemlisinin çocukların gelişim özelliklerinin buna uygun olmadığını belirtmiştir. Ayrıca, Babayiğit vd. tarafından gerçekleştirilen, ilkokul birinci sınıfta dik temel harflerle yazma öğretiminin incelenmesi çalışmasında öğretmen görüşleri alınmıştır. Söz konusu çalışmada öğretmenler; 1. sınıf çocuğunun küçük kas hazır bulunuşluğu tamamlanamadığından, çocukların kas yapısının bitişik eğik yazı için uygun olmadığını, kasları gelişmeyen el becerisi zayıf çocuğun bitişik eğik yazıyı beceremediği ve kendini başarısız hissettiğini, bitişik eğik yazı öğretiminin oldukça zor olduğunu, bu zorluğun; bitişik eğik yazının velinin tanımadığı bir yazı stili olması ve bitişik eğik yazı daha zor olmasından dolayı evde de devam ettiğini, velilerin harflerin yazımını pek bilmediği için çocuklara yardım etmekte zorlandığını hatta ev destekli çalışmalar yaparken çocukları yanlış yönlendirdiklerini belirtmişlerdir (Babayiğit, Karabay ve Metin, 2018). Bu da, çalışmamızda katılımcıların bitişik eğik yazıdaki en önemli verimsizlik ve başarısızlık sebepleri olarak belirttikleri; çocukların gelişim özellikleri ile aile ve çalışma ortamı ile paralellik göstermektedir.Yine, Avcı ve Şahin (2016) tarafından yapılan araştırmada öğretmenler, ses temelli cümle yöntemi uygulanırken kullanılan bitişik eğik harflerle yazan öğrencilerin, yazdıktan sonra kendi yazısını okuyamadıkları ya da yanlış okudukları belirtmişlerdir. Ayrıca, öğretimde harflerin okunuşunda, sessiz harflerin sonuna herhangi bir sesli harf getirmeden yapılmakta. Ancak veliler bunu bilmediğinden harfleri çocuklara öğretirken sessiz harflerin arkasına sesli harf getirerek okuyor/okutuyor. Böyle bir durumda da çocukların karmaşa yaşadıkları yönünde görüş bildirmişlerdir. Bununla beraber bu yaş çocukların gelişim özelliklerinin bütünü görmeyi gerektirdiğini, uygulanan bu yöntemin parçayı görmeye yönlendirdiği için çocukların zorlandıklarını ifade etmişlerdir. Akman ve Aşkın tarafından yapılan çalışmada, bitişik eğik yazının olumsuz yanlarının olup olmadığı sorusuna, 13 sınıf öğretmeni (\%72), olumsuz yanlarının bulunduğu yönünde cevap vermişlerdir. Öğretmenler genel olarak, öğrencilerin düz yazıyı tercih ettiklerini, bitişik eğik yazı yazmakta zorlandıklarını belirtmişlerdir. Güzel yazan öğrencilerin yazılarının estetik durmakla birlikte, sayılarının çok az olduğunu ve öğrencilerin çoğunun yazılarının okunmadığını ifade etmişlerdir. Ses temelli cümle yönteminin olumsuz yanlarının olup olmadığ1 sorusuna, 10 sınıf öğretmeni (\%56), olumsuz 
yönleri bulunduğu yönünde cevap vermiştir. Görüşme yapılan sınıf öğretmenleri, öğrencilerin okuduklarını anlamakta zorlandıklarını, okuma ve yazmada bütünlük sağlanamadığını, öğrencilerin noktalama işaretlerini geç kavradığını söylemişlerdir (Akman ve Aşkın, 2012).

Katılımcıların, ses temelli cümle yöntemi ile yürüttükleri ilk okuma yazma öğretimi sürecinde öğrencilerin zorlandıkları aşamalar için belirttikleri ile öğrencilerin ilk okuma - yazma öğretiminde yetersizlik gösterdikleri alanlar için belirtikleri arasında anlamlı fark bulunmuştur. Katılımciların \%11,1'i ses temelli cümle yöntemi ile ilk okuma - yazma öğretimi sürecinde öğrencilerin hazırlık aşamasında, \%15,7'si sesi hissetme tanıma aşaması, \%15,7'si sesi okuma-yazma aşaması, \%26,6'sı hece oluşturma aşaması, \%11,8'ikelime oluşturma aşaması, $\% 6^{\prime}$ sı cümle oluşturma aşaması, \%6,3'ümetin oluşturma aşaması ve $\% 6,6$ 'sıokuryazarlığa ulaşma aşamalarında genel olarak zorlandıklarını belirtirken, katılımcı öğretmenlerin \%6,5'i başarısız öğrencilerin öğretim süreci sonunda hazırlık aşamasında, \%17,6'sısesi hissetme tanıma aşamasında, \%18,5'i sesi okuma-yazma aşamasında, \%33,3'ü hece oluşturma aşamasında, \%8'ikelime oluşturma aşamasında, \%4,6'sıcümle oluşturma aşaması, \%1,9'umetin oluşturma aşaması ve \%9, $6^{\prime}$ sı ise okuryazarlığa ulaşma aşamasında yetersizlik gösterdiklerini belirtmişlerdir. $\mathrm{Bu}$ da bize, öğrencilerin zorlandığı alanlar ile yetersiz oldukları alanların farklı olduğunu göstermektedir.

Araştırma bulgu ve sonuçları doğrultusunda şu önerileri getirmek mümkündür:

- Öğretim programları hazırlanırken ilk okuma - yazma öğretimi sürecinde, öğretmen ihtiyaçlarını karşılayacak ve öğretimin her aşamasında soru, sorunlarına cevap verecek şekilde hazırlanmalıdır.

- Öğretmenlere ilk okuma-yazma öğretimi ve yönteme ilişkin eğitim verilmelidir. $\mathrm{Bu}$, ilçe düzeyinde her yıl, birinci sinıflarda eğitim-öğretimi yürüten-yürütecek öğretmenlerle sınırlı olabilir. Böylece süreç içinde yöntemin uygulanmasında karşılaşılan sorunların giderilmesi mümkün olabilir.

- Programda ilk okuma-yazma öğretimi için öngörülen yöntemin basamaklarına uygun etkili, model olacak uygulama örneklerine yer verilmelidir. 
- İlk okuma-yazma öğretiminde öğretmenin, çocukların gelişim özelliklerini daim göz önünde bulundurmalı, öğretim sürecinde en çok zorlandıkları aşama olan hece oluşturma aşamasına daha özenli, seçici hazırlanmalı ve bu aşamayı daha yavaş, bireysel olarak yürütmeli, temel paydaşlardan biri olan aileyi bilinçlendirerek mutlaka sürece dahil etmelidir.

- İlk okuma-yazma öğretiminde yöntem değişikliğine sık gidilmemelidir. Bu değişiklik, paydaşların dahil edildiği saha çalışmaları sonuçlarına göre, geniş ve uzun süreli pilot uygulamalar sonucunda yapılmalıdır.

- İlk okuma-yazma öğretiminde de başarı daha çok öğretmen niteliğine bağlıdır. Bundan hareketle süreçte öğretmenler konuya ilişkin seminer, çalıştay, hizmet içi eğitim vb. alınmalıdır. Program ve yöntem değişikliklerinde bu bilgilendirme çalışmaları mutlaka ve zorunlu olarak gerçekleştirilmelidir.

- İlk okuma-yazma öğretiminin temel aktörü öğretmenlerin, teşvik edilerek bilimsel çalışmalara katılımı sağlanmalıdır.

- İlk okuma-yazma öğretiminde özellikle nitelikli yazı beceri, başarısında sorun yaşanmakta olduğu ifade edilmektedir. Belirtilen en önemli sebep ise sınıf mevcutlarının yüksek olması ve öğretmenin öğrenci ile birebir ilgilenip rehberlik yapamamasıdır. Bundan hareketle, özellikle birinci sinıfların oluşumuna özel önem verilmeli ve öğrenci sayısının mümkün olan ez az seviyede tutulmasinda hassasiyet gösterilmelidir.

- Programda, yazı bölümüne özel önem verilmeli ve mutlaka yazıya ilişkin tüm bilgiler uygun, doğru örnekler, öğretmen ve öğrenciye etkin model olacak şekilde yer almalıdır. Temel materyaller özellikleri ile mutlaka belirtilmelidir. Kasım 1997 de Talim Terbiye Kurulu kararı 2482 sayılı Tebliğler Dergisinde yayınlanan ve 1968 programına giren İlköğretim Kurumları Türkçe Eğitimi Yazı Programının örneği gibi. Bunun öğretmen, öğrenci vs. tüm paydaşlar açısından etki ve katkısı çok yükssek olacaktır. 
EXTENDED ABSTRACT

\section{Evaluation of Sound-based Sentence Method of Teaching Reading and Writing from The Teacher's Perspective

Literacy is acquired in the first grade of primary school, and its development and use last for life as it is one of the most important skills in someone's social and educational life.

There are many methods of literacy teaching. Literacy teaching was carried out with the sentence method under the 1968 Primary Education Curriculum until the Ministry of National Education made the soundbased sentence method and cursive handwriting operative in the whole country beginning the 2005-2006 academic years.

One of the many aspects that play a role in literacy teaching is the method followed by the teacher. The aim of this study is to determine the success of the sound-based sentence method by determining the success of the students in application stages of the method, the deficiencies and their reasons, the effects of these reasons and to suggest solutions to achieve effective application of sound-based sentence method, particularly on individual steps.

\section{Method}

The research model of the studyis the descriptive research approach. The universe of the study is the primary school teachers who teach reading and writing using the sound-based sentence method; the sample of the study is 332 primary school teachers who participated in the study and performed the teaching of reading and writing using the sound-based sentence method. The sample of the study consisted of teachers working public schools in the province of Ministry of Education in Istanbul and 
who taught by the sound-based sentence method. With the appropriate sampling method (Gay, Mills and Airasian, 2006), the schools in Istanbul were scanned and the data collection tool which was developed by the researcher was applied to the primary school teachers who carried out the teaching of reading and writing by the sound-based sentence method. Descriptive statistics of 332 class teachers who participated in the study are given in Table 1.

The data collection tool contains 10 questions about personal and professional knowledge and 15 questions about the Elementary Program (2005) sound-based sentence method. The questionnaire, which was prepared by taking a total of 3 experts' opinions, including 1 researcher, and involving descriptive questions, was applied to 30 teachers as pilot application. As a result of this application, 5 questions were reviewed and finalized.

Descriptive statistics such as frequency and percentage are included in the analysis of the data obtained with the data collection tool which contains depictive questions. In order to obtain more detailed information about the questions which are appropriate for the purpose of the research, chi - square statistic, which is a cross tabulation analysis, was used.

\section{Results and Discussion}

Based on the findings of the data analysis, the following conclusions have been reached. $61.4 \%$ of the participants were female and $38.6 \%$ were male. While $77.4 \%$ of the participants graduated from classroom teacher training institutions, $21.4 \%$ of them graduated from a non-branch undergraduate program and worked as a classroom teacher by taking the formation program. $78.9 \%$ have at least undergraduate degree. $73.5 \%$ have professional seniority over 15 years. $88.6 \%$ taught first year students for more than 3 years / time and $9.9 \%$ used the sound-based sentence method 3-5 times. $51.5 \%$ of the teachers had a class size below 45 students while they were teaching and $62.7 \%$ participated in the preparatory training on literacy teaching with sound-based sentence method.

$26.5 \%$ of the participants stated that the explanations about soundbased sentence method in the primary education curriculum were suffi- 
cient. 244 (73.5\%) participants who did not find the explanations (2005) sufficient ranked the inadequate aspects according to their importance (1st most - 5th less important) (table 3). 88 out of 174 stated the explanations regarding the method and application steps, 30 out of 150 stated assessment and evaluation, 60 out of 189 stated examples of practice, 27 out of 122 stated quality and usage of materials, and 48 out of 166 stated explanations and issues related to writing as the most important deficiency.

$24.4 \%$ of the participants stated that they could find solutions to their problems in the Primary Education Program while 19\% could not and $56.6 \%$ partially could. $31.9 \%$ of the participants found sufficient examples of implementation while $16.6 \%$ did not.

The stage where students have difficulty was preparation for $11.1 \%$, sound recognition for $15.7 \%$, to read and write the sound for $15.7 \%$, forming syllables for $26.6 \%$, forming words for $11.8 \%$, forming sentences for $6 \%$, forming texts for $6.3 \%$ and achieving literacy for $6.6 \%$. The number of students who failed to show the necessary achievements at the end of the process was $1-3$ for $80.6 \%, 4-6$ for $14.2 \%, 7-9$ for $3.1 \%$ and 10 or more for $2.2 \%$. The stage where unsuccessful students show the most inefficiency was preparation for $6.5 \%$, sound recognition for $17.6 \%$, to read and write the sound for $18.5 \%$, forming syllables for $33.3 \%$, forming words for $8 \%$, forming sentences for $4.6 \%$, forming texts for $1.9 \%$ and achieving literacy for $9.6 \%$.

When asked whether the planning of literacy teaching by using sound-based sentence method was easy, simple and short-term; $76.7 \%$, $69.2 \%$ and $73.5 \%$ of participants said yes, in that order.Activities were easy for $53.8 \%$, simple for $44.6 \%$ and short-term for $36 \%$. Assessment and evaluation was easy for $63.4 \%$, simple for $57.3 \%$ and short-term for $50.5 \%$. Implementation was easy for $39.3 \%$, simple for $35.8 \%$ and shortterm for $35.8 \%$.

$64.4 \%$ of participants found the scheduled period of time for literacy teaching with sound-based sentence method adequate for efficient teaching while $11.7 \%$ of participants found cursive handwriting successful.

$293(88.3 \%)$ teachers who did not find cursive handwriting successful ranked the inadequacies according to their importance (1st most - 5th less important, in Table 9). The most important inadequacy was inability 
to write cursively for 23 out of 260, illegibility for 49 out of 247 , inability to write letters for 100 out of 255, inability to join letters for 19 out of 209, inability to leave space between words for 1 out of 131, spelling and punctuation for 3 out of 95, inability to fit words in a line for 6 out of 127 stated.

The most important reason of insufficiency of cursive handwriting was the insufficiency of explanations and examples of application of writing program for 46 out of 128, the developmental characteristics of children for 144 out of 240 , the quality of materials for 10 out of 106 , the inadequacy of time for 12 out of 122, crowded classrooms for 49 out of 220, family and studying environment for 36 out of 229 and other reasons for 3 out of 18 .

The stages at which students have difficulty and the ones that students fail are different, which means there is a difference between the stages of hardships and failure $\left(\chi^{2}(49)=322,10 ; p<0,001\right)$.

These are the recommendations formulated:

- Curriculum should meet the needs of teachers at every stage.

- Teachers should be given annual seminars on literacy teaching.

- The curriculum should include examples of effective application of steps of the method.

- The teacher should take into consideration the developmental characteristics of children, be careful about the syllable formation phase which is the most challenging stage that requires individual attention, and include the family in the process.

- Changes in literacy teaching method should be made as a result of large and long-term pilot implementations and not be frequent.

- Success in literacy teaching depends on the quality of teachers. Teachers should participate in seminars, workshops, in-service trainings and scientific studies especially in case of program and method changes.

- The most important problem about achieving writing skills is lack of one-on-one interaction with students. First grade class sizes should be kept at the lowest.

- Writing program should include appropriate examples. Basic materials must be specified with their properties. 


\section{Kaynakça / References}

Akman, E. ve Aşkın, İ. (2012). Ses temelli cümle yöntemine eleştirel bir bakış. GEFAD / GUJGEF, 32(1), 11-13.

Aktürk,Y. ve Mentiş Taş, A. (2011). İlk okuma yazma öğretiminde ses temelli cümle yönteminin uygulanmasına ilişkin öğretmen görüşleri. Adnan Menderes Üniversitesi Eğitim Fakültesi Ĕ̆itim Bilimleri Dergisi, 2(1), 2737.

Akıncı, M., Bektaş, S., Gülle,T., Kurt, S. ve Kurt, Y. (2016). Ses temelli cümle yöntemi ile okuma-yazma eğitimi. Boğaziçi Üniversitesi Eğitim Dergisi, 33 (2), 97-115.

Akyol, H. (2015). Türkçe ilkokuma - yazma öğretimi. (14.Baskı). Ankara: Pegem Akademi Yayınclik.

Arslan, D. ve Ilgın, H. (2010). Öğretmen ve öğrencilerin bitişik eğik yazı ile ilgili görüşler. İnönü Üniversitesi Ĕ̆itim Fakültesi Dergisi. 11 (2), 69-92.

Avcı, Y. E., Şahin, M. (2016). Ses temelli okuma-yazma öğretiminde sınıf öğretmenlerinin karşılaştığı sorunların incelenmesi. Sosyal Bilimler Enstitüsü Dergisi, (6-7), 59-79.

Babayiğit, Ö., Karabay, F.H., ve Metin, Z. (2018). İlkokul birinci sinıfta dil temel harflerle yazma öğretiminin incelenmesi. Uluslararası Türk Eğitim Bilimleri Dergisi, 6 (11), 53-58.

Beyazıt, N. (2007). İlk okuma yazma öğretiminin kazandırılmasında çözümleme yöntemi veses temelli cümle yönteminin farklı bakış açılarıyla değerlendirilmesi, Yayımlanmamış Yüksek Lisans Tezi, Hatay: Mustafa Kemal Üniversitesi Eğitim Enstitüsü.

Binbaşığlu, C. (1989). İlkokuma ve yazma öğretiminde yöntem sorunu. Çă̆daş Ĕ̆itim, 14(150), 3-7.

Binbaşıŏlu, C. (1999). İlk okuma ve yazma öğretiminin ve alfabe kitaplarının tarihsel gelişimi. Eğitim ve Bilim, 14 (114), 8-32.

Binbaşıŏlu, C. (2003). Eğitim ve öğretim üzerine yazılar. Ankara: Nobel Yayınları.

Cemaloğlu, N. ve Yıldırım, K. (2005). İlkokuma yazma öğretimi. Ankara: Nobel Yayın Dağıtım.

Çelenk, S. (1999). Illkokuma yazma öğretimi. Artım Yayınları. Ankara.

Çelenk, S. (2002). "illk okuma yazma öğretiminde karşılaşılan sorunlara ilişkin öğretmen görüşleri". İlköğretim Online, 1(2) 4047. http://ilkogretim-online.org.tr. 
Çelenk, S. (2003). Ilkokuma yazma programı ve öğretimi. Ankara: Anı Yayıncilik.

Çelenk, S. (2005). Yeni ilk okuma yazma öğretim programının değgişik öğretim yaklaşımları ışı̆̆ında değerlendirilmesi. Eğitimde Yansımalar VIII: Yeni İlköğretim Programlarını Değerlendirme Sempozyumu. Kayseri. 100.

Gay L.R., Mills, G.E., and Airasian, P. (2006) Educational research (8. Edition). Ohio: Pearson.

Gliner, J. A., Morgan, G. A. ve Leech N. L. (2009). Uygulamada araştırma yöntemleri: desen ve analizi bütünleştiren yaklaşım. (Çev. Editörü S. Turan) Ankara: Nobel Akademik Yayıncilik.

Göçer, A. (2014). Etkinlik temelli ilkokuma ve yazma öğretimi. (2. Baskı). Ankara: Pegem Akademi.

Gray, S.W. (1964). Okuma ve yazı öğretimi. (Çev. Nejat Yüzbaşığulları). Öğretmen Kitapları: 86.

Güleryüz, H., (1998). Programlanmış ilkokuma yazma öğretimi kuram ve uygulamaları. Ankara: Pegem A Yayıncilık.

Güneş, F. (1997). Okuma yazma öğretimi ve beyin teknolojisi. Ankara: Ocak Yayınları.

Güneş, F. (2005). Niçin ses temelli cümle yöntemi. Eğitimde Yansımalar VIII: Yeni İlköğretim Programlarını Değerlendirme Sempozyumu. Kayseri. 136-145.

Güneş, F. (2007). Ses temelli cümle yöntemi ve zihinsel yapılandırma. Ankara: Nobel Yayın Dağıtım.

Kadıoğlu Ateş, H., Ada, S. ve Baysal, N. (2014). Ses temelli cümle yöntemine göre ilkokuma yazma öğretimine ilişkin öğretmen görüşleri. İZ̈̈ Sosyal Bilimler Dergisi, 3 (5), 79-96.

Kültür Bakanlığı. (1936). İlk okul programı. İstanbul: Devlet Basımevi.

Maarif Vekâleti. (1924). İlk mekteplerin müfredat programı. İstanbul: Matbaa-î Âmire.

Maarif Vekâleti. (1926). İlk mekteplerin müfredat programı. İstanbul: Millî Matbaa.

Milli Eğitim Bakanlığı. (1948). İlk okul programı. İstanbul: Milli Eğitim Basımevi.

Milli Eğitim Bakanlığı. (1968). İlkokul programı. İstanbul: Milli Eğitim Basımevi. 
Milli Eğitim Bakanlığ1. (2009). İlköğretim türkçe dersi öğretim programı ve kılavuzu (1- 5. sinıflar). Ankara: Devlet Kitapları Müdürlüğü Basım Evi.

Milli Eğitim Bakanlığı. (2015). Türkçe dersi (1-8. Sınıflar) öğretim programı. Ankara: Devlet Kitapları Müdürlüğü Basım Evi.

Milli Eğitim Bakanlığı. (2018). Türkçe dersi öğretim programı (ilkokul ve ortaokul 1, 2, 3, 4, 5, 6, 7 ve 8. Sinıflar). Ankara: Devlet Kitapları Müdürlüğü Basım Evi.

Şahin, İ., İnci, S., Turan, H., ve Apak Ö. (14-16 Kasım, 2005). İlk okuma yazma öğretiminde ses temelli cümle yöntemiyle çözümleme yönteminin karşılaştırılması. Eğitimde Yansımalar: VIII Yeni İlköğretim Programlarını Değerlendirme Sempozyumu (s. 159-176). 14-16 Kasım Erciyes Üniversitesi, Sabanc1 Kültür Sitesi, Kayseri.

Şahin, A. ve Akyol, H. (2006). İlk okuma-yazma öğretiminde kullanılan çözümleme ve bireşim yöntemlerinin uygulamalı olarak karşılaştırılması. Ulusal Sınıf Öğretmenliği Kongresi Gazi Üniversitesi Gazi Ĕ̆itim Fakültesi Sınıf Öğretmenliği Ana Bilim Dalı. Kök Yayıncılık. Ankara. (1). 3-14.

Tok, Ş., Türkay Tok, N. ve Mazı, A. (2008). İlk okuma yazma öğretiminde çözümleme ve ses temelli cümle yöntemlerinin değerlendirilmesi. Kuram ve Uygulamada Ĕ̆itim Yönetimi, 53, 123-144.

Yılmaz, M. (2009). İlk okuma yazma öğretiminde ses temelli cümle yönteminin öğretmen görüşlerine göre değerlendirilmesi: Hatay ili örneği. Mustafa Kemal Üniversitesi Sosyal Bilimler Enstitüsü Dergisi, 6 (12), 164-175.

\section{Kaynakça Bilgisi / Citation Information}

Sağırlı, M. (2019). Ses temelli cümle yönteminin ilk okuma-yazma öğretimi üzerindeki başarısının öğretmen açısından değerlendirilmesi. OPUS-Uluslararası Toplum Araştırmaları Merkezi, 13(19), 852-883. DOI: 10.26466/opus.596841 